\title{
Early Childhood Pedagogy: Veronica Pacini- Ketchabaw Interviews Peter Moss
}

\begin{abstract}
Peter Moss is emeritus professor of early childhood provision at UCL Institute of Education, University College London. He has researched and written on many subjects, including early childhood education and care and the relationship between early childhood and compulsory education; the relationship between employment, care, and gender; and democracy in education. Much of his work has been cross-national, and he has led a European Commission network on childcare and an international network on parental leave. From 2005 to 2016 he coedited the book series Contesting Early Childhood, whose aim is to question "the current dominant discourses surrounding early childhood, and offer instead alternative narratives of an area that is now made up of a multitude of perspectives." His books include Beyond Quality in Early Childhood Education and Care (with Gunilla Dahlberg and Alan Pence), Radical Education and the Common School (with Michael Fielding), Social Pedagogy and Working with Children and Young People (edited with Claire Cameron), and Transformative Change and Real Utopias in Early Childhood Education. Most recently he worked with Reggio Emilia to produce an English-language book of the work of Loris Malaguzzi, which was published in 2016-Loris Malaguzzi and the Schools of Reggio Emilia: A Selection of His Writings and Speeches, 1945-1993. Email: peter.moss@ucl.ac.uk

Veronica Pacini-Ketchabaw is professor of early childhood education in the Faculty of Education at Western University in Ontario, Canada, and codirector of the British Columbia Early Childhood Pedagogies Network. Her writing and research contribute to the Common Worlds Research Collective (tracing children's relations with places, materials, and other species) and the Early Childhood Pedagogies Collaboratory (experimenting with the contours, conditions, and complexities of $21^{\text {st }}$-century pedagogies). She is the principal investigator of the SSHRC Insight Grant Transforming Waste Pedagogies in Early Childhood Education and the SSHRC Partnership Development Grant Exploring Climate Change Pedagogies with Children. She is the author/coauthor of more than 40 peer-reviewed articles and six books: The Common Worlds of Children and Animals: Relational Ethics for Entangled Lives (Routledge, 2018), Encounters with Materials in Early Childhood Education (Routledge, 2017), Unsettling the Colonial Places and Spaces of Early Childhood Education (Routledge, 2015), Youth Work, Early Education, and Psychology: Liminal Encounters (Palgrave, 2016), Journeys: Reconceptualizing Early Childhood Practices (University of Toronto Press, 2014), and Flows, Rhythms, and Intensities of Early Childhood Education Curriculum (Peter Lang, 2010). Email: vpacinik@uwo.ca
\end{abstract}

This conversation between Peter Moss and Veronica Pacini-Ketchabaw addresses a wide range of subjects, from Moss's early writings on the ethical and political struggles of early childhood education to the challenging suggestions of pedagogical experimentation.
Veronica: Let me start by welcoming everyone to the Ontario Provincial Centres of Excellence Exposures series. I'm a professor of early childhood education at Western University and one of the codirectors of the Provincial Centre of Excellence for Early Years and Child Care, one of three centres that has been funded by the Ontario Ministry of Education.

Before proceeding any further I'd like to suggest that we all carefully consider the land we are on today. Think about the history of the place in which you are-who is there, who is not allowed to be there, who is represented and who is not represented. We meet today, here, to think about pedagogy and specifically to consider European perspectives on early education. And as I think about the place I'm in right now, I wonder how we at the Provincial Centre might continue to think with these European early childhood education legacies that we're going to be sharing today, and at the same time address the painful colonial histories present in Canada.

For those people who are joining the Exposures series for the first time, the Provincial Centre is engaged in the process of orienting pedagogists. Although the idea of a pedagogist will be unfamiliar to many of you, it has deep roots in continental Europe, and I know that Peter [Moss] will be sharing with us a bit of this history.

It also has some history in Canada with the Investigating Quality project that began in 2007 and continues today in British Columbia. 
The event today, called an exposure, is part of the orientation of pedagogists. The purpose of exposures is to enrich pedagogists' pedagogical dispositions and sensitivities, as well as to provide an opportunity to the broader early childhood education community to be exposed to the ideas the pedagogists are thinking with.

Our Twitter handle and hashtag will be shared by Andrew shortly. And just in case, it's @EYpedagogists and the Exposures series hashtag is CApedagogists.

\section{The importance of alternative discourses}

I'd like to begin with a paragraph in my favourite book that Peter has co-written, that has stayed with me for a very, very long time and continues to challenge me to this day. The book is From Children's Services to Children's Spaces and it was published in 2002. The quote goes something like this: "The British pride themselves on being a pragmatic people, with the practical term of mind. Problems are stated and solutions found. Theory is suspect and an excuse for unwarranted and distorting prejudice. This view is expressed by many. Other charges laid against theory include incomprehensibility and distracting irrelevance." Can you comment on this statement?

Peter: I do not believe there is a choice between "theory" and "no theory," or, indeed, between theory and practice. Nor that somehow evidence or experience can be neutrally produced and interpreted, and that actions selfevidently and inevitably follow. Theories shape our understandings and govern our actions, whether we recognize this or not, through the concepts and explanations that provide us with tools for making sense of the world and our experience.

Veronica: I think it's such a powerful quote and so relevant today.

Two other important texts_-Valuing Quality published in 1994 and then Beyond Quality published in 1999-present the challenging idea that we need alternative discourses in early childhood education. Can you speak about the importance of alternative discourses? Why, even though they are difficult to think with, they are necessary today?

Peter: I think we live in a time when we are told that "there is no alternative." And of course, that phrase "there is no alternative" will forever be associated with Margaret Thatcher, who would often stand up and tell us there was no alternative to whatever action she was taking. There's a Brazilian writer called Roberto Unger who I like very much, and he uses the term "dictatorship of no alternative" (Unger, 2005a, p. 1). And to some extent this authoritarian way of thinking and talking is a result of living at a time when there is a very strong dominant discourse of neoliberalism, which I see as being a very important political and ideological frame that has shaped so much of our lives in the last 30 or 40 years. And it works very much by saying there is no alternative-no alternative to a world of competition, individual choice, calculation, commodification, and marketization. This is, the neoliberal says, just how things are; we can explain everything in life by applying this particular way of thinking, this totalizing theory about life; the only option is to work within this framework.

This clearly is problematic on several levels. On one level, if there's a big problem in neoliberalism (or whatever other dominant story you're being told there is no alternative to), if it begins to blow up, then you may be left with nothing to replace it with. I think we're actually entering a period in which neoliberalism is blowing up, when we can see increasingly clearly that it is a failed project, a story that no longer makes sense. And there's a necessity therefore to begin to have alternative ideas to put forward, alternative policies. But, of course, to acknowledge and encourage alternatives, to challenge the dictatorship of no alternative, is profoundly democratic, because I think the essence of democracy is that there are different perspectives, different views, different ways of understanding the world, different values. So, if you are to say there is no alternative, then you are really denying diversity, 
multiplicity, complexity, all of these things.

So it seems to me that the whole idea that there is no alternative is really very insidious and very dangerous. And, of course, what's very encouraging in many fields is that people are coming up with alternatives. There are always alternatives if you care to listen. And that's true as much in early childhood as in any other field, and the book series that Veronica referred to, Contesting Early Childhood, has been a platform where people who are working with alternatives can actually talk about them, tell their alternative narratives, and, equally important, show that they can be put to work, because you want an alternative that you can actually work with in early childhood settings.

So my interest has been in arguing that there are alternatives and that—and I think it's really critical today-having alternatives around is vital and urgent if we are to be ready when the dominant story of neoliberalism blows up. We need to have alternatives. We need to be ready with other ways of thinking and with proposals and experience about how we put them to work, because I don't think it's much good just having theories which you can't actually work with and put into practice.

Recently I have begun to think and write in terms of stories. So theories-for example, like neoliberalism-are stories that we tell ourselves, stories by which we make sense of the world. And so, rather than just talking about alternative theories, we can also talk about telling alternative stories. I like that idea that we can tell alternative stories, but I've become interested, not only in what those alternative stories could be-and of course there are many, many of them-but as I say, what you do with them, how you can put them to work. If you believe, for example, in democracy as a fundamental value, what would that actually look like in a school or nursery?

So I think the search for new stories is really important, but it's also very difficult to do, because the pressures, particularly in the English-language world, are very great, as the English-language world has been so dominated by neoliberalism and this idea that there is no alternative. I think it's very difficult to break free, because of course what you're surrounded by are people all talking about the same things, as if there is no alternative, as if it would be crazy to think something else, and that clearly there couldn't be any other way of talking. So it's quite difficult to have the confidence and the belief in yourself and in others to actually go with alternatives.

Veronica: Yes, absolutely. One of the alternatives that you have been putting forward through your work has been the shift from seeing early childhood education as a service to seeing it as an ethical political project. And, as you said, that is a very difficult way of communicating this alternative to the English-speaking world.

\section{Early childhood education as an ethical political project}

Veronica: I wonder if you can speak about this idea of early childhood education as an ethical political project, which elaborate on in your book with Gunilla Dahlberg, Ethics and Politics. What do you mean by the idea that early childhood education is an ethical political project?

Peter: Well, I would say, by the way, that we're talking about all education in fact, even though we're putting "early childhood" before it in this interview. I think that everything I'm talking about is about the whole range of education, and indeed I think one of the problems we face is the tendency to look at just one bit of education and not the whole range of it. Because I would argue that the whole of education-and indeed most other forms of provision that we make for children and young people, indeed adults also-is a political project. What do I mean by that? Well, I mean that with education, or whatever else you are dealing with, you need to start with political questions.

I can quote Loris Malaguzzi here when he says that education is "always a political discourse whether we know it 
or not. It is about working with cultural choices, but it clearly also means working with political choices" (Cagliari, Castegnetti, Giudici, Rinaldi, Vecchi, \& Moss, 2016, p. 267). Leaving to one side the very interesting idea of education being a cultural discourse calling for cultural choices, I think what Malaguzzi is saying and what I'm saying is that actually you need to start by asking political questions and that political questions have no one right technical answer.

To give an example, if I'm flying to Canada on a plane, I want the plane to be the result first and foremost of technical practice, involving technical choices to technical questions, the result of experts getting together and agreeing there is only one right way to build a plane so that it's safe and efficient. We might call it a "quality" plane, since it is based on universal and decontextualized principles and standards. I don't actually want to fly on a plane that's the result of political practice.

However, with education, we're dealing with something quite different, because there isn't one right way to "make" education. It is first and foremost a political practice, because there are lots of different ideas and different answers, many of them conflicting, to political questions, because different people will have different positions, views, perspectives. So it seems to me that the basic idea is that education, like similar activities, does not have one right technical answer. It has political answers, and those answers may be in conflict.

Let me give a few examples of political questions. What is our diagnosis of the times? That's a term that Karl Mannheim, the sociologist of education, used. So in other words, what do we think is going on in our world at this time? What are the main issues of the day? Because education should be engaging with these issues, with the conditions of the time. So to take an example, you could say that we're confronting converging environmental crises which are actually putting ourselves, humankind, not to mention other species, very much at peril. So if you think that is one of the issues of our times, then you need to ask, how does education relate to that?

A second question, of particular importance to Malaguzzi, is, what is your image of the child? Who do you think the child is? He says that a "declaration [about the image of the child] is not only a necessary act of clarity and correctness, it is the necessary premise for any pedagogical theory, and any pedagogical project" (Cagliari et al., 2016, p. 374). And I would go on to ask, what is your image of the educator?, which is really central to the sort of work you're presently engaging in.

And equally important, what is your image of the early childhood centre or school? Is it a kind of factory for producing outcomes, such as learning goals, school readiness, or human capital? Is it a business engaging in market activities, selling a commodity to parent-consumers? Or do you think of it in some other light? Is your image of the centre or the school as a public space where projects can be created by children and adults coming together?

Or, to give a couple more examples of political questions, without going through the whole list: What are the fundamental values of education? What ethics should education work with?, which takes you into the field of relational ethics. In other words, given that education is a relational practice because it involves people coconstructing knowledge in relationship with each other, then you have to choose what are the ethics that should underpin the relationships that exist in this process of co-construction and working together.

So, all of these and many, many more are political questions, and they will generate a wide and diverse range of answers, creating the potential for people to dialogue and indeed confront each other about these answers. Through this democratic process it may be possible to find some degree of consensus, but how far that will go is always open to question. The political choices you make provide the basis for constructing the sort of early childhood education that you want-what is considered a good or desirable education. 
As I say, the alternative which we have today under neoliberalism is to see education as, first and foremost, a technical practice, rather like building a plane, in fact. And this is based on asking and answering technical questions, of which the classic one is "What works?" What does the evidence tell us we should do to get children developing faster, or whatever?

Now, of course, within the neoliberal narrative, there's a whole range of implicit political questions and answers. But what you don't find in the neoliberal system is people actually acknowledging that they have asked and answered political questions and made political choices. They just pretend there is only one way to do things and the only thing you need to ask is "What works?"

So that was where Gunilla Dahlberg and I started our book Ethics and Politics in Early Childhood Education (Dahlberg \& Moss, 2005). We started by saying that we think today that early childhood education is treated as first and foremost a technical practice. And we wanted to say that it's actually first and foremost a political and ethical practice. So we are trying to reclaim politics and the political, to say we don't think they are dirty words, we think they are really important, and that what we want to see-and it's very difficult-is a democratic politics of education where people are putting forward alternative political choices, alternative stories, about the sort of education they think is important.

\section{Relational ethics: The ethics of care and the ethics of an encounter}

Veronica: I want to pick up on this discussion on ethics. You mentioned that what you're talking about is relational ethics. And I think about how most of us in early childhood education have been thinking about following ethical guidelines. Can you elaborate on how relational ethics is different from following ethical principles that have already been established and that perhaps might follow those neoliberal values you spoke about?

Peter: I'm sure there is a place for guidelines to guide how we do certain things in a proper way. The problem with guidelines, as discussed by Zygmunt Bauman (1993), is the danger of following any ethical rule book, procedures, guidelines, of being told basically how you should behave, of being basically given a list of ethical do's and don'ts. Because Bauman says that actually we have to take responsibility for our ethical behaviour rather than fall back on a rule book. But having said that, there is a place no doubt for rule books in certain circumstances, especially if we don't follow them blindly by taking no personal responsibility for what we do.

It seems to me that some of the ethical approaches-I don't actually know if that is the right word-that Gunilla and I were interested in, and that we wrote about in our book, place a big responsibility on individuals in relationship with other people to make their own judgments. So, for example, we were very interested in the ideas around an ethics of care, which is a whole field that has emerged out of feminist scholarship since the 1990s, and which has been raising the importance of care as a political and ethical concept. Joan Tronto describes an ethics of care as combining two elements: "a practice rather than a set of rules or principles ... [involving] particular acts of caring" and a "general habit of mind" to care that should inform all aspects of moral life (Tronto, 1993, p. 127, emphasis added). That habit of mind includes several qualities or values: attentiveness (to the needs of others), responsibility, competence, and responsiveness. Furthermore, caring, understood as an ethic, should be widely applied: it is, say Tronto and coauthor Bernice Fisher, a "species activity that includes everything we do to maintain, continue and repair our 'world' so we can live in it as well as possible" (Fisher \& Tronto, 1990, p. 19) — so care, not only of other people, but also of communities, societies, and the physical environment.

So an ethics of care gives you a broad frame, but actually what that means in practice you have to work out for yourself, but always with others. So in an early childhood centre or school, that would be a subject for ongoing 
discussion and documentation by adults about how they are actually working with an ethics of care-having, of course, first made a political choice that this is an ethical approach you will work with.

And to digress, I react very much against terms like "child care service" or "daycare service" because it seems to me that all provisions that we make for children should be concerned with care understood as an ethics of care. We should think of care as an ethics, not as a way of describing a particular service.

The other ethics that Gunilla and I were very interested in when writing our book was the "ethics of an encounter." That is very much a reaction against a longstanding Western way of relating with other people and other things: the "will to know" in which you seek to know them in your own terms and so grasp them and make them into the same. In other words, you try and understand other people or other things through your own logic, through your own way of seeing the world: "Oh yes," you go, "you're a bit like this or that, like something I understand already." So you try and use your way of thinking and understanding things to make sense of somebody else, and doing that, you actually deny their otherness, their singularity. And it becomes quite dangerous, because you end up applying your categories, your classifications, your way of looking at the world onto somebody else, and I think that we probably do that all the time in education and elsewhere. Gunilla has described how the ethics of an encounter confronts educators with profound questions, "such as how the encounter with Otherness, with difference can take place as responsibly as possible-as something which the so-called 'free thought' cannot grasp through categories, classifications, and thematizations" (Dahlberg, 2003, p. 270).

So these relational ethics - the ethics of care and the ethics of an encounter-are examples of what it might mean to work with ethics in a way that it isn't a straitjacket, but it gives you a framework for thinking and constantly exploring what it means, because I think that's what we have to do in life. We have to constantly say, I want to work with this ethical approach, but actually I'm not very good at doing it all the time. I need to constantly question with other people whether what I and we are doing is ethical in relation to, say, an ethics of care or an ethics of an encounter. We need to be constantly questioning these things.

Veronica: Yes, thank you for bringing up that point. It is difficult to engage with an ethics of care or the ethics of an encounter. Trying to not take for granted the other with our own framework, whether it's children or educators . It is just a very difficult task.

\section{The problem of language}

Veronica: My next question is around language. And I know you talked in the beginning a little bit about using new language. You said we need new forms of education or alternatives to neoliberalism-even big words like neoliberalism are unfamiliar to our early childhood education discourses, our dominant early childhood education discourses in the Western world. Yet, at the same time, the alternatives cannot do without it. Can you please talk about the importance of shaping language, of not just staying with the language we are accustomed to using in early childhood education. And why is it even necessary?

Peter: Obviously language carries with it, embedded in it, all sorts of cultural ideas, concepts, ways of looking at the world. So it's the way we make, we build stories; we use words, vocabulary to build stories or theories or understandings, whatever you want to call it. And that language is not neutral; it carries our cultures and our perspectives. I have to say first of all, I'm linguistically incompetent. I only speak English, to my profound shame, but I have done a lot of work involving translation and translators, and that has made me extremely conscious of the importance of language and the problems of actually translating from one language to another. 
Many words don't translate very well because they carry particular ideas that don't work well in another language. Translation into English is a very big problem because English is so dominant and many things get translated into English. Native English speakers are often not curious about the original language. All they want is to have a translation served up for them in English so they can know what has been written or said in another language. But what can happen is that the meaning of a word or concept in another language can disappear, be lost in translation. So, for example, where I work at the London Institute of Education, some of us have become very interested in the continental European discipline and theory of social pedagogy, which your previous exposé [Silvana Calaprice] was talking about very interestingly. But social pedagogy often gets translated into English as education, and it's not education in the school sense at all, and the pedagogue is not a teacher, but the profession often gets translated in that way. (For a fuller discussion, see Moss \& Petrie, 2019.)

So, the problem of language is really important. It can lead to people completely misunderstanding or missing something. But if we look at it in another way, the word that doesn't work in another language can lead to a very interesting conversation, because you can say, let's talk about this word that does not translate well, try and explain it to me, this word, this concept you have in Spanish, Italian, whatever it is. So that's a general observation: that native English speakers I think need to be much more curious about other languages and be very careful that they don't ignore important ideas by insisting they have to be fitted into some sort of English mistranslation.

More generally, one of the pleasures of my last few years has been working with people in Reggio Emilia on producing a book in English of Loris Malaguzzi's writings and speeches, which involved a huge amount of work on translation (Cagliari et al., 2016). What strikes me in English about Malaguzzi is the language he uses, it's so light, it's so poetic, it's so pleasurable. He talks about joy, he talks about wonder, he talks about amazement, and so on. He uses all these words, and through these words he builds up a quite different set of ideas about children, adults, schools, education, and it's very obvious that by using those words, by the vocabulary he works with, he's able to build up a different story, very different to the extremely prosaic language that dominates the English-language world when it comes to education, and which so often makes reading articles or books on early childhood education in English so boring and depressing, with those words like program, outcome, quality, human capital, investment, and so on and so forth. It's the language of the worst sort of technocrats. But of course, that's why it's in use, because it's about building up an idea of education as a technical practice in which technicians apply technologies.

So, what you get in so much early childhood education today is really a manual about how to work the technology. Which is why reading Malaguzzi-and not only him, but other people in, for example, the Contesting Early Childhood book series-is just so liberating, because once you can free your mind of all these words and open yourself to other words, you can begin to tell and listen to other stories. So yes, that's why language is absolutely critical, and if you can break old habits of speech, if you can say to yourself that I'm not going to use a word such as "quality" in the next months, but instead I'm going to talk about what I really desire, then you might find that quite liberating, as I have done.

Veronica: Thanks, Peter. I think I really resonate with what you are saying. We are often accused of using too many big words, or taking too long to say something when we are drawing on work written in other languages.

Peter: So can I just say that it's also a very good example of this ethics of an encounter, because if you are an English speaker and you encounter another language, if what you're trying to do is to force that language into your English language, you're trying to make the other into the same, and in that process you will lose the singularity of that other language, the diversity or whatever you want to call it. So it's a very good example of the danger of trying to grasp the other and make the other into something you can understand, into the same. 
Veronica: And then there is also the language that other theories or other narratives or others' stories bring. I remember being introduced to the poststructural narrative (that you wrote about in Beyond Quality, and in other books) and how challenging it was at the beginning...

Peter: Yes, I agree. I suppose unlike some people, I came to a lot of these alternative theories and perspectives quite late in life. I would say that until the 1990s, I was a positivist, and I'm still very familiar with the language of positivism, which is quite useful to know. But then I was quite liberated by being introduced to other theoretical languages, even though I have to say I've found them-and I still find some of them-very difficult, partly because I must admit that people don't always write very clearly in some of the other languages. But the difficulty of understanding is also because you're being asked to enter a world which you had never entered into before, and to think differently, to see the world in a different way. And I think that's a large part of the problem in coming into relationship with new theories, because they ask you to actually turn everything on its head and see things in quite different ways. So, I think that is difficult, and I speak from firsthand experience, and I quite often find myself drifting back into more positivistic thinking and language. So actually working with the new theoretical languages, having to struggle to write or talk in a new language, is important.

Veronica: Yes, that is our challenge. As we develop the pedagogist network, how might we sync with other languages, other narratives?

\section{Situating pedagogy within the conditions of our times}

Veronica: Peter, you mentioned the book that you have coedited with your colleagues from Reggio Emilia. For me this is one of the first books that clearly outlines how the Reggio Emilia project was situated within the conditions of our times-what you call the diagnosis of our times. What do you think-and you started to think about this above-are the conditions of the times that early childhood education needs to be responding to today? If Malaguzzi was alive today, what might he be telling us we need to respond to?

Peter: I'm sure he would see the issues of environment, and I mean more than just global heating but the many other things that are going on. Because in fact, in the years before he died in 1994, he was already talking about the emerging environmental crises. And of course, the environmental crises are also economic crises, because we are facing today the consequences of an economic system that has been built on excessive extraction, consumption, and greed and a lack of care for the world we live in. So, I'm sure he would also be saying the issue today is the creation of new ideas about economy. And by the way, it seems to me it's impossible to talk about early childhood education without thinking about the environment and without thinking about the economy. Because early childhood education today has become so bound up in very instrumental neoliberal economic ideas like human capital and return on investment, which are very much about the idea of exploiting resources and so on and so forth.

So I think he would be very interested in that. I think he would have been very interested in the implications of new technologies, artificial intelligence, and so forth. I think the third issue he would be very engaged with would be the state of democracy, because it's fairly clear that across the world today democracy is in some trouble. And not just the democracy of the ballot box, though that matters, but in lots of different ways. So I think he would be very concerned to engage with how education can be involved in renewing democracy. He probably would remember John Dewey's comment that democracy needs to be reborn in every generation and that education must be the midwife.

I think that another issue that he'd be very interested in is the need to restore solidarity, after the damage caused 
to it by neoliberalism's drive for competition and individualism. Related to that, the importance of recognizing complexity and interconnectedness. All these things are connected, of course. You could say that we can't address the environmental crises unless we deal with the economy, and the economy is also about issues of solidarity, so the question of rebuilding solidarity in our communities and in our societies is very pressing, I think, today. Indeed, as Erik Olin Wright has argued (2019), solidarity, democracy, and equality are three core values that need to be renewed, restored, built up again as the basis for more just and sustainable societies.

And I guess Malaguzzi would be thinking all the time, what is the role of education in this? What sort of education is going to be relevant to those sorts of challenges to our society? For as he said, "our conception of pedagogy is dynamic, not mummified. Either pedagogy-like all the human sciences-is remade, reconstructed and updated based on the new conditions of the times, or it loses its nature, its function, its proper capacity to correspond to the times it lives in, and above all to foresee, anticipate and prepare the days of tomorrow" (Cagliari et al., 2016, p. 143). Malaguzzi would probably be talking about the need for education, faced by today's conditions, to be innovative, creative, and experimental, because we have to come up with new ideas if we're going to survive. So I like to think that these would be some of the issues that he would be working on today.

Veronica: Thanks, Peter. That is very provocative to create a connection between the political, the ecological, the social, and the very question of education. Because, like you said, education has become more of a technical issue $\ldots$

\section{Transformative change}

I want to talk about your scholarship on transformation. You rethink the idea of change and introduce transformative change, which you put into conversation with the idea of experimentation. I wonder if you can talk about what you mean by transformative change. Why do we need to think about transformative change through experimentation?

Peter: Well, I suppose that there is a lot of talk about change, partly because of neoliberalism's constant restlessness. Organizations are constantly changing and arguably far too often and far too much. So, the addition of "transformative" in the title of the book-Transformative Change and Real Utopias in Early Childhood Education (Moss, 2013) - is trying to qualify change as more than reshuffling the deck chairs all the time. It's about change as fundamental rethinking. As Michel Foucault puts it, "As soon as one no longer thinks things as one formerly thought them, transformation becomes very urgent, very difficult and quite possible" (Foucault, 1988, p. 155), and that's what I talk about in the book.

So, if we think differently, if we adopt or we work with different stories to the ones that we've been working with before, if we see things in different ways, then that leads to "transformative change." What seemed terribly important before, like human capital or whatever, no longer seems very important, and other things become very important. So rethinking is really, really important. And that comes back to language. And then there's the question of reforming once you are rethinking, because rethinking gives you an answer to that question "Where to?" Where do I want to get to, what is the direction of travel? And then the question is, how might we get there, how do we reform to get there?

And in the book, and subsequently, I was quite influenced by the American sociologist Erik Olin Wright and his writing about what he called "real utopias." He thought that desirability is very important when talking about utopias: We need to know what we want. But it is not enough; we have to be able to achieve it. And to do that, we need to address viability and achievability; we need to be able to say how would we get from here to there. Wright is also very much in favour of quite incremental changes - that we do a bit of this, we do a bit of that, try this, we try 
that, and gradually things move. He rejects the idea of revolutionary change or rapid ruptures; he says that really doesn't have a very happy history. But what we do, as long as we know where we're trying to get to, is constantly try things out. We do this, we do that, we move gradually towards where we want to get to. Now, I guess this is where experimentation comes in. You get ideas; you want to try them out and create something new. You want to produce a new project, whatever it is, and you have to try it and see what happens. So I think experimentation fits into that idea about how things might move in the direction you want.

And I come back now to Milton Friedman, who was a very influential figure in the rise and rise of neoliberalism. He was an economist, and he was part of a whole group of people working on neoliberal ideas after the Second World War, and who were waiting for their chance. And he said, back in the 1960s, before neoliberalism became the powerful force it is today, "Only a crisis-actual or perceived-produces real change. When that crisis occurs, the actions that are taken depend on the ideas that are lying around. That, I believe, is our basic function: to develop alternatives to existing policies, to keep them alive and available until the politically impossible becomes politically inevitable" (Friedman, 1982, p. ix).

And that seems to me to be very good strategic advice, and it fits in, I think, with what Wright is saying. Because I think my optimistic reading — and I may be completely wrong - is that we are on the cusp of change. Neoliberalism may be running its course, though it is by no means dead. It's got quite a lot of life left in it. But we have to be ready now with alternatives for when "the politically impossible becomes politically inevitable."

It's no good waiting for the banks to blow up again or whatever it is that heralds the demise of neoliberalism and then say, what are we going to do? So, in early childhood education, I think it's important, even though the opportunities to put things into practice are currently limited, to be working on alternative ideas and policies. We need to know what we want, what we think is desirable, and we need to develop ideas about policy and practice, which might make those desirable futures possible. Like Friedman, we need to be ready when fundamental change happens.

Veronica: Thanks, Peter. Yes.

Peter: Can I just add that one thing about Malaguzzi which is really important was he had very clear ideas about what he wanted, but he and the other people in Reggio Emilia were, and still are, intensely practical. He was constantly saying, under what conditions can we develop the sort of pedagogy that we want? And they were very good at putting in place conditions that enabled them to achieve what they wanted, pedagogically. So I think that question - "What conditions do we need?"-should be at the forefront of our mind all the time. We must constantly link practice and policy. I'm sorry, I interrupted you.

\section{Locally situated pedagogy}

Veronica: That's great, because your comment connects to the question I want to ask. Going back to our previous exposure with Italian professor Silvana Calaprice ... She shared with us that pedagogy is never about reproducing an educational model. I wonder what your thoughts are on this idea (never reproducing a particular model) in relation to the reproduction of the Reggio Emilia "approach"? I ask this question because you have been so close to the history of Reggio Emilia and how Reggio Emilia has influenced early childhood education.

Peter: Well, I think you talked earlier about Reggio as a project and that's very much how I see it, in fact. I always remember going to another Italian city, which had also done very important educational work, and the person directing the schools there said, "We have undertaken a local cultural project of education." That seems to me a 
very good description of what has happened in Reggio and many other cities in Italy, and indeed in other parts of the world. And the point about these projects is that they emerged out of particular historical, political, and cultural contexts. So I am probably in a minority of one in not being very comfortable with the term "Reggio Emilia approach" because I think it suggests that Reggio is a template to be copied and not a singular project.

On the other hand, I think Reggio Emilia is incredibly important, first of all because it shows that alternative projects are possible, and that's really important, as indeed are other examples of past and present alternatives. But also because I think it constantly acts as a provocation to us, having asked its political questions and made its political choices. It provokes us to ask: What are our political questions? What would our political choices be? And I think, too, they have developed some ways of working that could be or are being worked with in other places. I mean, pedagogical documentation is a very good example that I think now is very widely used. Also, some of the roles they have developed, like pedagogistas, could be applicable.

So, I think one could take from them some ways of working. And also that question, what conditions do we need? We have a project, what do we need to do to put it to work? So I can't see that a place with a very different context could actually copy Reggio Emilia, but it could work with Reggio Emilia to construct its own local cultural project of education.

Veronica: Thank you for that provocation.

\section{Democracy in the 21 st century}

Veronica: I want to ask about the concept of democracy in the 21 st century. You used the term democracy a few times. I wonder what relations are you referring and gesturing towards when you think about democracy? And what do you think democracy has become in neoliberal early childhood education? What might it mean to experiment with transformative democracies or transformative democracy going forward?

Peter: Well, first of all, it's important to look back and remember that the idea of democracy as a fundamental value in education is not new. It goes back a long way, and it's a very important idea in the tradition of progressive education, associated with figures such as John Dewey, Célestin Freinet, Paolo Freire, and of course Loris Malaguzzi. So we are standing on the shoulders of giants, and to put forward democracy as an important educational idea is not new, though under neoliberalism it has been squeezed out, because I think neoliberalism isn't terribly enamoured of democracy.

It seems to me we can understand democracy as being multifaceted. It is obviously a way of governing, through the ballot boxes and the rule of law and freedom of expression and so on. But Dewey talks about democracy as a way of living and relating, as "primarily a mode of associated living embedded in the culture and social relationships of everyday life ... a personal way of individual life" (Dewey, 1939, p. 2). So, you could say it's a relational ethic, about how we should relate to each other, how we should be listening and dialoguing and being open to difference and so on.

And of course that means that we can talk about democracy as an everyday practice: how we live with each other in everyday institutions. Tom Bentley talks about how "building everyday democracy depends on applying its principles to everyday institutions through which people make their choices and develop their identities" (Bentley, 2005), and early childhood centres and schools would be good examples of such everyday institutions.

Another theme is that democracy is something you learn through living it. You don't really learn it through being given lessons in it. So that means a lot of thought needs to go into the practices, the relationships in everyday 
life, in the way "minor politics" is conducted, how small things are decided and arrived at. While in pedagogy, Reggio Emilia practices a pedagogy of listening, which seems to me to be an intrinsically democratic approach to pedagogy.

They also have what they call "social management" of early childhood centres, which is an intrinsically democratic approach to the management of these services based on elections of teachers, parents, and other citizens. So I think democracy can infuse education in all sorts of ways, from management through to small questions about eating and food and all sorts of places in between. But I think it's one of the big challenges we face-repairing democracy after neoliberalism - and quite a lot of people are, and have been, writing about the role of education in that important task.

Veronica: Thank you, Peter. You made me think about what democracy might mean as education engages with climate change, or with migration, or with new digital ecologies, and so on and so forth. Perhaps these are the very questions we need to continue to ask ourselves in early childhood education.

\section{Experimentation}

Veronica: One last question before we open for the audience to ask questions. Experimentation. One of the books in the series (by Liselott Olsen) addressed pedagogical experimentation, drawing from Deleuze. You also address this concept in your book on transformational change. This is a concept that we have proposed to pedagogists to think with-certainly not an easy task. We already have preconceived ideas of what experimentation is, and quickly conflate it with the idea of experiment. So, can you say a few words about how you use the concept of experimentation?

Peter: The Brazilian philosopher Roberto Unger talks about democratic experimentation, which he describes as "an innovative collective practice, moving forward the qualitative provision of the services themselves." He says, "That can no longer happen in our current understanding of efficiency and production by the mechanical transmission of innovation from the top. It can only happen through the organisation of a collective experimental practice from below ... Democracy is not just one more terrain for the institutional innovation that I advocate. It is the most important terrain" (Unger, 2005b, pp. 179, 182). He's saying that if we are to be creative and move forward, then we have to tap into ideas coming from below and try them out and do this in a democratic way. So he connects democracy to experimentation.

One of the things that interests me is about the potential of the early childhood centre and the school for projects which are not necessarily pedagogical. And they can be projects which come out of local communities, local families, and the response of the centre to the needs and the desires of those communities and families. And I've written in Transformative Change and Real Utopias about examples from my country, where we have had very innovative centres, community-based centres, which, as well as providing education, have provided a host of other projects. They've experimented, you could say, with projects in response to what they see as the needs of their community. To take an example of a centre serving a very poor district with a lot of migrants in it, they provided legal services, language services, a range of other support for families experiencing different sorts of problems and so on and so forth. So that's experimentation. You're actually saying, look, this community, this group of families, they need something. Let's see what we can do to actually use our public space, our public resource here to support them. And I believe very strongly that the school and the centre should be places which are seen as public space and public resources.

Pedagogically, I think it's very interesting to think about the role of Loris Malaguzzi. He was a prodigious reader, 
endlessly fascinated with what was going on in the world, with new ideas, with new theories, with new perspectives. He was really reading into all sorts of things. He would have sessions with teachers, educators, and other staff, and at these sessions he would talk about what he'd been reading, about this new theory or different perspective, and he might talk about this for two or three hours, I am told. And I've talked to some of the teachers he talked with, and they say, "We'd go away and we'd say that was something we didn't really understand very much about, but it was really exciting," and over time they would come to understand better and become more and more interested.

I think we should try to understand more about this role that Malaguzzi had in the organization, the school system. He had this very interesting role of mediating between the wider world and the schools in Reggio Emilia. He was a sort of conduit, a channel for bringing in ideas. And then they would all talk about these ideas, and then they would say, well, what can we do with them? Can we try them out? So they would experiment with them, but they wouldn't stop at that.

They would then evaluate or research how that went, and then they would go back and discuss to get a better understanding. How did that experiment go? Malaguzzi and other people from Reggio use the words "experiment" and "experimentation" all the time, along with "research" - and research for them is, in part, a way of trying to understand better how their experimentation was working out. So experimentation is part of a system which is supported by pedagogistas and where people have time to document and look at what they're doing and talk about it. So experimentation is not dropped in. It's actually embedded in how their work evolves, with experimentation as the kind of motor of evolution: bringing in new ideas, trying them out, checking them out, seeing how they work, and then perhaps trying them out in a different way.

So I think that's a very good example of the dynamic role of experimentation, but I think you have to keep reminding people that Malaguzzi was actually a local civil servant. He was employed by the municipality. Why don't we have today in municipalities people who have that sort of role-if you like, a kind of intellectual role where they are constantly feeding in new thinking, new ideas, getting things going, getting movement happening, getting movement and experimentation happening? Why don't we have that today? Is it because municipalities are reduced today to administration and management? Don't we need something more than that?

So I think experimentation can be seen as an extremely powerful force for movement. For getting things moving all the time, relating experimentation and movement to your diagnosis of the times.

Veronica: Thank you. What better place to pass it on to the audience as we think about experimenting. 


\section{References}

Bauman, Z. (1993). Postmodern ethics. Blackwell.

Cagliari, P., Castegnetti, M., Giudici, C., Rinaldi, C., Vecchi, V., \& Moss, P. (Eds.). (2016). Loris Malaguzzi and the schools of Reggio Emilia: A selection of his writings and speeches 1945-1993. Routledge.

Dahlberg, G. (2003). Pedagogy as a loci of an ethics of an encounter. In M. Bloch, K. Holmlund, I. Moqvist \& T. Popkewitz (Eds.), Governing children, families and education: Restructuring the welfare state. Palgrave Macmillan.

Dahlberg, G., \& Moss, P. (2005). Ethics and politics in early childhood education. Routledge.

Dewey, J. (1976). Creative democracy: The task before us. In J. Boydston (Ed.), John Dewey: The later works, 1925-1953, Vol. 14. Southern Illinois University Press.

Fisher, B., \& Tronto, J. (1990). Toward a feminist theory of caring. In E. Abel \& M. Nelson (Eds.), Circles of care, work, and identity in women's lives. SUNY Press.

Foucault, M. (1988). Politics, philosophy, culture: Interviews and other writings 1977-1984 (A. Sheridan et al., Trans.). Routledge.

Friedman, M. (1982). Capitalism and freedom (rev. ed.). University of Chicago Press. (Original work published 1962)

Moss, P., \& Petrie, P. (2019). Education and social pedagogy: What relationship? London Review of Education, 17(3), 393-405. https://doi. org/10.18546/LRE.17.3.13

Tronto, J. (1993). Moral boundaries: A political argument for the ethics of care. Routledge.

Unger, R. M. (2005a). What should the left propose? Verso.

Unger, R. M. (2005b). The future of the left: James Crabtree interviews Roberto Unger. Renewal, 13(2/3), 173-184.

Wright, E. O. (2019). How to be an anti-capitalist in the $21^{\text {st }}$ century. Verso. 